OPEN ACCESS

Edited by:

Miguel Melendro,

National University of Distance

Education (UNED), Spain

Reviewed by:

Paulo Delgado,

Polytechnic Institute of Porto,

Portugal

Alejandro Pulgarin

University of Manizales, Colombia

Elias Manuel Said-Hung, Universidad Internacional De La Rioja,

Spain

*Correspondence Rosa Marí-Ytarte

Rosa.Mari@uclm.es

Roberto Moreno-López

Roberto.Moreno@uclm.es

Rut Barranco-Barroso

Rut.Barranco@uclm.es

Specialty section:

This article was submitted to

Educational Psychology,

a section of the journal

Frontiers in Psychology

Received: 18 February 2020

Accepted: 15 May 2020

Published: 19 May 2020

Citation:

Marí-Ytarte R, Moreno-López $R$ and Barranco-Barroso $R$ (2020) Sex and Relationship Education for the Autonomy and Emotional

Well-Being of Young People.

Front. Psychol. 11:1280.

doi: 10.3389/fpsyg.2020.01280

\section{Sex and Relationship Education for the Autonomy and Emotional Well-Being of Young People}

\author{
Rosa Mari-Ytarte*, Roberto Moreno-López* and Rut Barranco-Barroso* \\ Department of Pedagogy, University of Castilla-La Mancha, Education and Society Research Group (GIES), Talavera de la \\ Reina, Spain
}

In the transition to adulthood, sexuality and emotional relationships constitute one of the most important dimensions for the achievement of personal autonomy and emotional well-being. Despite advances in sex education, sexuality, and relationships remain conflictive areas in the development of young people. Inequalities between men and women, gender identities and sexual violence, along with the beliefs and expectations surrounding these issues, persist as handicaps to having a fulfilling relationship and sex life. At this stage, emotional well-being is also consolidated by one's perception of sexuality and relationships from models learned in childhood, in which gender stereotypes and sexuality based on relationships of domination and discrimination persist. Therefore, we examined how the sexual beliefs and practices reported by young people correlate with their level of personal autonomy and responsibility in terms of risky behaviors and toxic relationships. The study shows the extent to which sexual beliefs and habits are linked to decision-making, personal development and social problems derived from conflictive relationships, affecting young people's overall well-being. A questionnaire was developed based on the theoretical constructs of comprehensive sexuality and equality education (United Nations Educational Scientific and Cultural Organization [UNESCO], 2010, 2018; World Health Organization [WHO], 2010) with the following dimensions: sex education, sexual habits and practices, motivations, concepts, and beliefs about sexuality. It was distributed in institutions of higher education (N579) in Spain, Portugal, Argentina, and Brazil, and the results revealed a discrepancy between the reported practices and behaviors and the beliefs and models of reference. Key issues included sexuality and relationships as an aspect of personal life that generates confusion and conflict, as well as the propagation of gender and sexist stereotypes that influence young people's emotional well-being, particularly important aspect in those young people who are training as future education professional.

Keywords: young people, autonomy, emotional well-being, relationships, sexuality, education

\section{INTRODUCTION}

The World Health Organization (WHO) describes sexual health as a state of physical, emotional, mental, and social well-being in relation to sexuality; it is not merely the absence of disease, dysfunction or infirmity. Sexual health requires a positive and respectful approach to sexuality and sexual relationships, as well as the possibility of having pleasurable and safe sexual experiences, 
free of coercion, discrimination, and violence. For sexual health to be attained and maintained, the sexual rights of all persons must be respected, protected, and fulfilled (World Health Organization [WHO], 2002, p. 5).

Sexual health is therefore a permanent experience of physical, psychological and sociocultural well-being. Such is the case that we can observe subjects' level of sexual health based on their responsible sexual behaviors. The latter include not only safe sexual relations, but also sexual behaviors in which autonomy, maturity, honesty, respect, consent, protection, and the pursuit of well-being come into play.

It is currently argued that sexuality is a basic human function involving physiological, emotional, and cognitive factors and connected to other personal and psychological aspects such as well-being, health and quality of life. In this study, we understand sexual satisfaction as the level of pleasure, wellbeing, and adjustment observed during a sexual interaction (Rodríguez, 2010).

Sexual satisfaction constitutes a human right and a key element of quality of life associated with a better state of physical and mental health (Whipple et al., 2003; Moore and Davidson, 2006; Levin, 2007; Scott et al., 2012). Connections between sexual satisfaction, physical health, psychological health, general wellbeing (Scott et al., 2012), and quality of life (Davidson et al., 2009) have been identified.

Also, the relationship between sexual satisfaction and psychological variables, including body image and self-esteem, has been widely studied. In this regard, higher self-esteem has been found to be associated with lower body dissatisfaction (Mellor et al., 2010; Salvador et al., 2010). When the relationship between sexual satisfaction and self-esteem has been explored, positive correlations have been found between these variables (Calado et al., 2004).

Unawareness of the emotional, mental, and psychological aspects of sexual health is highly problematic. If young people are uninformed of the importance of these aspects and of sexual pleasure and how that pleasure can be achieved and maintained, they may, as evidenced by the findings of Bakker and Vanwesenbeeck (2006), fail to seek help in the face of problems with sexual function. In the absence of a broader education on sexual health, young people are likely to perceive sexual problems as normal and run the risk of experiencing physical and psychological side effects.

The United Nations Educational Scientific and Cultural Organization [UNESCO], 2010 highlights the need to implement effective sexuality education, given that the cultural values and religious beliefs of all people (and particularly young people) have a major impact on the understanding of this issue and on relationships with other adults and their communities. Comprehensive sexuality education (CSE) responds to this demand, empowering young people to make informed decisions about relationships and sexuality while providing them with the necessary knowledge and skills to lead a satisfactory personal, social, and sex life.

In general, a sense of well-being is an indicator of quality of life that may be understood as the result of the perception of quality of life. In other words, well-being is an interpretation of quality of life based on subjective experience and environmental and personal filters (Langlois and Anderson, 2002). And psychological well-being emphasizes the attainment of values that make people feel alive and authentic, that allow them to grow as individuals, more than activities that give them pleasure or take away pain (Zubieta et al., 2012). Psychological well-being focuses on the study of personal growth, positive experiences, subjective well-being or happiness level and the optimal functioning of people, communities, and society (Duckworth et al., 2005; Snyder and Lopez, 2005).

The study of sexuality and its relationship with well-being has been a recurring research theme for decades (Munpoz and Revenga, 2005; Borrego and Enriìuez, 2013). Also, in its 2010 report, the WHO recommends appropriate sex education for individuals' level of development, based on gender equality, self-determination and acceptance of diversity and backed by scientific knowledge (Martiìnez-Ailvarez et al., 2012). However, it was not until a few years ago that scientific and academic interest in issues such as gender experienced a considerable boom, due largely to the crusade undertaken by multiple social movements (Platero and Rosón, 2012).

Knowledge of and attitudes toward sexuality adopted as an individual matures are largely derived from what is transmitted by the different social-educational contexts to which the subject is exposed during his or her socialization process. On the other hand, the vast majority of studies have focused almost exclusively on the behavioral component of sexuality, such as types of sexual behavior, contraceptive use, risks, number of partners, etc. (Santín et al., 2003; Alencar et al., 2008; Altmann, 2009; Andrade et al., 2009; García-Vega et al., 2010, 2012; Kornblit and Ezequiel, 2015; Martín et al., 2018; Nascimento et al., 2018).

Scientific literature shows that young people adopt liberal, erotophilic attitudes toward sexuality, and especially toward what is more socially visible and acceptable, such as heterosexuality or coitus (García-Vega et al., 2017). However, their attitudes are less positive toward other issues not linked to the dominant norm, such as some sexual practices or the expression of sexual and gender diversity (Claramunt and Huertas, 1999). In addition, numerous stereotypes and myths associated with sexuality are perpetuated due to a lack of education, the view of sexuality as taboo and the predominance of normative values associated with conservative and religious morality (López, 2015).

In line with the above, it appears that overall, young people continue to assign stereotypical roles to men and women in relation to their experience of sexuality. In this regard, Sierra et al. (2007) studied the attitudes of 400 Spanish university students toward sexuality and concluded that; in general, sexist attitudes persist in which the possibility of gender equality is not considered.

Several studies have found gender differences in terms of both behaviors and feelings around sexuality, where women seem more focused on emotional issues and men on sexual behaviors (Friedrich et al., 2000; Faílde et al., 2008; López et al., 2011; Larrañaga et al., 2012). Men begin having sexual relations sooner and have more sex partners and more casual encounters (Faílde et al., 2008; Petersen and Hyde, 2010). In addition, having 
sexual relations with different partners continues to be seen more positively by men than by women (Crawford and Popp, 2003).

In this sense, many differences are rooted in the different socialization processes for men and women, which demonstrate the importance of considering sociocultural factors when analyzing such differences ( $\mathrm{Li}$ et al., 2017).

In addition, gender and the experience thereof, or of nonnormative sexuality, appears as one of the main focuses of discrimination, especially in educational contexts (Generelo, 2016). In this sense, discrimination based on sex or gender is maintained by its invisibility or by maintaining active discriminatory behaviors (European Union Agency for Fundamental Rights, 2014).

At this time, sex education generally pivots on the coexistence of the moral-conservative model and the risk model (CarreraFernández et al., 2012). Therefore, it is essential that a high-quality relationship and sex education that contemplates sexuality as an inherent aspect of the human being (Fallas-Vargas et al., 2012; Rodríguez-Carrión and Traverso-Blanco, 2012) be integrated into the core educational process. Sex education is an essential support for the achievement of well-being and quality of life, as well as a right whose exercise allows informed decisions to be made (World Health Organization [WHO], 2010).

The World Health Organization [WHO], 2018 recommends implementing CSE programs that allow subjects to enjoy health, well-being and dignity, becoming aware of how the decisions they make affect not only their own well-being, but also that of other people. Meanwhile, the United Nations Educational Scientific and Cultural Organization [UNESCO] (2018) states that CSE programs are central to preparing young people for a safe, productive and full life. Marí et al. (2019) point out the importance of acquiring through these programs skills and competencies that allow subjects to discover and develop their own autonomy and well-being in relation to others, where sexuality, self-knowledge and personal relationships are points of reference to express themselves as well-rounded human beings. By promoting positive relationships between the subject and his or her surroundings, they promote positive, healthy changes, leaving behind the sex education models focused on the presence or absence of disease (Viejo et al., 2018).

\section{METHODOLOGY}

Our initial hypothesis is that the sex education young people receive and the beliefs and sexual behaviors derived from it have an impact on their emotional well-being as individuals and in their social relationships. We start with the premise that, as indicated by WHO and UNESCO, sexuality is a part of and necessary for emotional well-being in youth, influencing aspects related to health, social bonds, and personal autonomy. In addition, we agree that sexuality develops and is in turn influenced by the perceptions that young people have of it, based on educational models on topics such as ideology, gender equality, emotional bonds, and social relationships. Therefore, emotional well-being at this stage of life is presumably subject to a double need: the construction of personal identity (with sexuality as an important dimension of it) and social acceptance, especially by one's peer group. In the study, we explore the extent to which young people's perceptions, practices, and beliefs about their sexuality converge with those recognized by the WHO and UNESCO as positive for sexual fulfillment and emotional well-being at this stage of life.

Following the WHO's reports we share evidence that sexuality remains a social taboo that, in most societies, prevents educational institutions from providing a comprehensive education from early childhood that would enable one to approach one's first sexual relations with confidence, autonomy, and security. It is also observed that gender inequalities and the greater social vulnerability of girls persist as a problematic or risk factor in sexual relations. Taboos, preconceived ideas about what sex is and an incomplete sex education, or one limited to aspects concerning reproduction or health protection, have been identified. According to these reports, a heteronormative discourse persists that focuses mainly on genitality while excluding a positive, diverse view of sexuality that allows young adults to grow from their own sexual experiences confidently and autonomously.

The WHO and UNESCO indicate that sexuality affects young people's emotional well-being because relationships can become problematic if sexual experiences generate personal conflict, insecurity or submission to social models that contradict a young person's own identity, due to:

1. A lack of information and of a thorough, highquality education.

2. Mental maps and distorted beliefs about sexuality.

3. Inappropriate or risky behaviors due to a lack of education, communication, and autonomy.

4. The (distorted) sexualization of society, which implies its genitalization, its masculinization (women as objects), the dichotomy between sexual and emotional relationships and the linkage of the latter to the stable partnership.

\section{Study Population and Sample}

1. The sample focuses on the university population of two countries in Europe (Spain 26.3\%; Portugal 20.5\%) and two countries in Latin America (Brazil 35.3\%; Argentina 17.9\%), with a total of 579 respondents among university students in 2017. The following parameters were established for the representative study sample: sampling error of \pm 2.7 sigmas, confidence level of $95 \%$. The questionnaire was completed by a larger number of women (male representation was $4.3 \%$, an aspect that limited the interpretation of the results from a gender perspective and the explanatory nature of the sex variable (therefore the different weight of the sample does not allow for a gender analysis). The selection of this sample regarding its autonomy and emotional well-being linked to sexuality is defined by the great importance of this group, as future trainers and workers with children and teenagers since, whether or not explicitly, they will contribute through their practice to the sex education of the next generations. From a gender perspective, encompasses much more than biological 
sexual division. We have tried to show this in the dimensions studied, especially those relating to affective beliefs, behaviors, and relationships, and how gender identity and its expression is strongly linked to emotional and social well-being at this stage of life. Regarding age, $54.1 \%$ of the participants were in the under 25 age group and $45.9 \%$ were over the age of 25 . The criteria used to define the study sample were: (a) the minimum range: over 18 years old, since they were university students. (b) Regarding the maximum strip: up to 30 years. Being the most unifying criterion in most countries, which in the case of Argentina (National Youth Directorate) and Brazil (National Secretary of Youth) would be 29 years and in the case of Spain and Portugal (EU) would be 30 years, as pointed out in the European Union Strategy for Youth 2019-2027. According to the IEO, an Organization for IberoAmerican States, which also includes Spain and Portugal, the United Nations defined youth in 1985 between the ages of 15 and 24. However, according to the 2008 report, which came into force, the Ibero-American Convention on Youth Rights (CIDJ) came into force, it is noted that in Europe the age is up to 29-30 years (due to the prolongation of schooling and the delay of the age of formation of own families).

\section{Instrument, Categories and Analysis Procedure}

The study was carried out through an ad hoc questionnaire based on the categories defined by the WHO and UNESCO regarding emotional well-being linked to sexuality in young adulthood.

- Education received.

- Sexual practices and habits.

- Beliefs and expectations regarding sexuality.

- Emotional relationships.

WHO's categories define emotional well-being and mental health around sexuality within socio-cultural framework that influences each of the above dimensions in young people's personal development, such as:

- The social and cultural norms of the environment (beliefs, religion, and politics).

- The sociopolitical context (human rights and legislation).

- Gender or sociocultural inequalities (education level and gender).

- Sexual function and psychosexual orientation.

- Policies to prevent gender-based violence and aid its victims and to prevent and control the spread of HIV and other sexually transmitted diseases.

For its part, the UNESCO defines sex education as a necessary resource backed by scientific evidence and aimed at promoting young people's health and well-being. In this regard, emotional well-being arising from sex education would be founded on:

- Comprehensive sex education backed by proven knowledge.

- Development of a sex-positive attitude.

- Safe sex practices and access to contraceptive methods.
- Incorporation of the gender perspective.

Based on these premises, we configured the dimensions of analysis for the data collection instrument and the variables that represent each dimension studied. This allowed us to examine young people's perceptions of each one in relation to the categories that define emotional well-being (WHO), as illustrated by the following list:

Dimension 1. Education sources: level and experience of sex education received. Associated variables:

1. Educasex: information and instruction on sexuality received in formal and informal educational contexts.

2. Personaldev: impact of education received on personal development.

3. Informalcompare: comparison of categories 1 and 2 .

Dimension 2. Habits: sexual behaviors and practices. Associated variables:

4. Firstsex: first sexual relations.

5. Numpartners: number of partners to date.

6. Freqsex: frequency of sexual practices.

7. Orgasm: relationship between sexuality and pleasure.

8. Contraceptives: safe sex and/or risky habits and practices.

9. Masturbation: practices and perception of autoerotism.

10. Fidelity: association of sexuality with stable partner relationships.

11. Samesex: perception and assessment of sexual relations with same-sex partners.

Dimension 3. Motivations: expectations of sexual relations. Associated variables:

12. Attractiveness. Qualities of the other person.

13. Personalpleasure. Seeking one's own satisfaction.

14. Otherperspleasure. Giving pleasure.

15. Bothpleasure. Giving and receiving pleasure.

16. Emoinvolve. Emotional involvement and intimate bonds.

17. Reproduction. Pregnancy and offspring.

Dimension 4. Sexual and gender identity concept: perception of sexual diversity. Associated variables:

18. Sexualiden. Sexual identity.

19. Gay. Homosexuality.

20. Lesbian. Lesbianism.

21. Transex. Transsexuality.

22. Ofgender. Gender identity.

23. Bisexual. Sexual relations with members of either sex.

24. Sexism. Prejudices based on gender.

25. Homophobia. Prejudices toward sexuality with samesex individuals.

26. Transphobia. Prejudices toward transsexuality.

Dimension. 5. Values regarding sexuality. Beliefs and values regarding sexuality.

Associated variables:

27. Varioussex. Having sexual relations with different partners at the same time. 
28. Lesscommit. Dissociation of sexuality and emotional or committed relationships.

29. Sexproblem. Promiscuity as a source of problems in relationships.

30. Immoralmasturb. Masturbation as a reprehensible practice.

31. Premarital. Assessment of sexual relations before marriage or stable partnership.

32. Withpeople. Experience and assessment of sexual relations with same-sex partners.

33. Prostitut. Perception and assessment of prostitution.

34. Eroticmat. Perception and assessment of the use of erotic toys.

35. Sexlove. Assessment of the link between sexuality and emotional bonds.

36. Otheroptions. Respect for sexual diversity.

37. Sexpleasure. Assessment of pleasure in sexual relations.

38. Menmore. Perception of the importance of sexuality linked to biological sex.

First, a descriptive analysis was conducted to calculate the contrast of means in order to describe the behavior of each dimension's variables in relation to the differentiating variables based on sex, age group, and continent. After this descriptive analysis, we performed the correlation analysis (Pearson's $r$ coefficient), where we determined a possible relationship between the different variables designed for each of the five components of well-being according to the WHO and UNESCO criteria. The probability value established for this study was $p<0.05$. Finally, we performed a factor analysis of rotated components and principal components and $\mathrm{KMO}$ test in order to determine the main components for the development of discourses within the predictive rotation of the relationship between variables. Regarding the analysis procedure, descriptive statistics were prepared with the IBM SPSS statistics 22 program.

\section{RESULTS}

\section{Contrast of Means Results}

After applying the contrast of means across all dimensions and their variables, and with age and continent serving as differentiating variables of the mean, the results were statistically significant to our study. The results exhibit significance in all variables and all cases with regards to differences by age group and by continent.

\section{Dimension 1. Education Sources: Level and Experience of Sex Education Received}

In particular, all categories associated with the Education dimension have a perfect result and, as illustrated in Table 1, the young women especially value the formal education received above learning in informal contexts, particularly in Argentina and Brazil. Likewise, individuals under the age of 25 respond positively to this education. Individuals over the age of 25 (1.78) and Europeans (1.78) attribute greater importance to academic education than individuals under the age of 25 and Latin Americans (1.39). In contrast, individuals over the age of 25 (1.64) and young Latin American women (1.77) assign greater importance to sex education contribution to personal development. Finally, in terms of formal versus informal sex education, by age group, to people over the age of 25 (1.76) than to younger respondents (1.63); and by continent, to Latin Americans (1.83) than to Europeans (1.62).

\section{Dimension 2. Habits: Sexual Behaviors and Practices}

In terms of the sexual habits reported by the young people surveyed, statistical significance was found based on age group, the statistically significant variables were $5,6,7$, and 8 : number of partners (significance 0.001), frequency of sexual relations (significance 0.023 ), orgasm (significance 0.000 ), and contraception (significance 0.003). In addition, looking at differences by continent, the results have greater statistical significance in variables 5 and 6: significance 0.036 and 0.029 , respectively. In other words, in all categories that clearly link sexuality to pleasure-seeking and personal satisfaction in all groups and countries.

\section{Dimension 3. Motivations: Expectations of Sexual Relations}

We found perfect significance levels in relation to age groups, we find important data in relation to variables 15 and 17: pleasure of both (significance 0.036 ) and emotional involvement (significance 0.032). Regarding continent of origin, we observe statistical significance in variables 12 and 15: partner attractiveness (significance 0.025 ) and pleasure of both (significance 0.005). In terms of personal motivation to have sexual relations, pleasure from the relations and the possibility of reproduction, are more important in this dimension.

\section{Dimension 4. Sexual and Gender Identity Concept: Perception of Sexual Diversity}

In the contrast of means, we find relevant results with perfect significance levels when differentiating by continent in variables 19 and 20: gay concept (significance 0.000) and lesbian concept (significance 0.000). Also noteworthy is the high statistical significance of variables 23 and 24: bisexuality (significance 0.037 ) and sexism (significance 0.002). If we differentiate by age groups, the significant variables are 19 and 23: gay (significance 0.005) and bisexuality (significance 0.045). In this regard, the results show a largely heteronormative, traditional perception of sexuality. Sexual diversity is accepted but barely represented as a value in one's own sexual experience.

\section{Dimension 5. Values Regarding Sexuality. Beliefs and Values Regarding Sexuality}

The contrast of means yields relevant results when differentiating by continent in variables 28,29 , and 37 : better sexuality with less commitment (significance 0.000), youth promiscuity as problematic (significance 0.001), and sex linked to pleasure (significance 0.008), which is also statistically significant with respect to age (significance 0.000). Regarding the variable 33 relating to prostitution, this is little accepted 
TABLE 1 | Contrast of means - sex education sources.

\begin{tabular}{|c|c|c|c|c|c|c|}
\hline & \multicolumn{3}{|c|}{ Age group } & \multicolumn{3}{|c|}{ Continent } \\
\hline & & Mean & Significance & & Mean & Significance \\
\hline \multirow[t]{2}{*}{ Academic sex education } & $<25$ & 1.78 & 0.000 & Eu & 1.78 & 0.000 \\
\hline & $>25$ & 1.45 & & Am & 1.39 & \\
\hline \multirow[t]{2}{*}{ Contribution of sex education to personal development } & $<25$ & 1.50 & 0.008 & $\mathrm{Eu}$ & 1.47 & 0.000 \\
\hline & $>25$ & 1.64 & & Am & 1.77 & \\
\hline \multirow[t]{2}{*}{ Formal sex education versus informal } & $<25$ & 1.63 & 0.004 & Eu & 1.62 & 0.000 \\
\hline & $>25$ & 1.76 & & Am & 1.83 & \\
\hline
\end{tabular}

Source: authors (1 = low well-being/2 = high well-being).

by the young women surveyed and that they give less importance to sex (variable 38). Beliefs and values regarding sexuality thus show, in all cases, that sexuality is perceived in terms of satisfaction and pleasure, and at the same time, that these variables are associated with the perception that women have about men.

\section{Correlation Results}

We applied Pearson's correlation analysis to determine the strength of the relationship between the described variables and the study dimensions. First, the results yielded a strong positive correlation between formal sex education versus informal and the contribution of sex education to personal development $(r=0.417$; significance 0.000) (Table 2).

When the correlation between the variables comprising dimension 2 (sexual habits) is calculated, as illustrated in Table 3, the data has strong statistical significance for the relationship between no. of partners and religion $(r=0.0497$; significance 0.000$)$ and to a lesser extent, age of first sexual relations ( $r=0.0266$; significance 0.000$)$, frequency of sexual relations ( $r=0.235$; significance 0.000$)$, and Orgasm $(r=0.0224$; significance 0.000 ). In the case of the orgasm variable, the only statistical significance concerns frequency of sexual relations ( $r=0.239$; significance 0.000$)$ and to a lesser extent, age of first sexual relations $(r=0.161$; significance $0.000)$. The rest of the variables do not show important correlations in this case.

Table 4 contains the correlation results for dimension 3 (motivations). The greatest statistical significance is observed between partner's pleasure and personal pleasure $(r=0.404$; significance 0.000$)$. Also, a negative correlation appears in the case of partner's pleasure and reproduction $(r=-0.200$; significance 0.000 ). The rest of the variables do not yield statistically significant results for this dimension.

In dimension 4 (sexual and gender identity concepts), we find a strong correlation between lesbian concept and gay concept ( $r=0.781$; significance 0.000 ), and to a lesser extent, between the sexism concept $(r=0.166$; significance 0.042$)$ and the lesbian concept variables. It is important to highlight the inverse correlation with the gender identity concept $(r=-0.163$; significance 0.044 ). When we focus on religion, the data is statistically significant for the sexual identity concept and the

TABLE 2 | Correlations for the education dimension.

\begin{tabular}{|c|c|c|c|c|}
\hline & & Religion & Academic sex education & $\begin{array}{c}\text { Formal sex education } \\
\text { versus informal }\end{array}$ \\
\hline \multirow{3}{*}{$\begin{array}{l}\text { Contribution of sex education } \\
\text { to personal development }\end{array}$} & Pearson correlation & 0.105 & -0.170 & 0.417 \\
\hline & Significance (one-tailed) & 0.043 & 0.000 & 0.000 \\
\hline & $N$ & 270 & 545 & 545 \\
\hline
\end{tabular}

Source: authors.

TABLE 3 | Correlations for the habits dimension.

\begin{tabular}{|c|c|c|c|c|c|}
\hline & & Religion & Age first sex $R$ & Frequency sex $R$ & Orgasm in sex $R$ \\
\hline \multirow[t]{3}{*}{ No. of partners } & Pearson correlation & 0.497 & 0.266 & 0.235 & 0.224 \\
\hline & Significance (one-tailed) & 0.000 & 0.000 & 0.000 & 0.000 \\
\hline & $N$ & 289 & 579 & 579 & 579 \\
\hline \multirow[t]{3}{*}{ Orgasm in sex $R$} & Pearson correlation & -0.066 & 0.161 & 0.293 & \\
\hline & Significance (one-tailed) & 0.133 & 0.000 & 0.000 & \\
\hline & $N$ & 289 & 579 & 579 & \\
\hline
\end{tabular}

Source: authors. 
TABLE 4 | Correlations for the motivations dimension.

\begin{tabular}{llcc}
\hline & & Personal pleasure & Reproduction \\
\hline $\begin{array}{l}\text { Partner's } \\
\text { attractiveness }\end{array}$ & $\begin{array}{l}\text { Pearson } \\
\text { correlation } \\
\text { Significance } \\
\text { (unilateral) }\end{array}$ & -0.146 & 0.094 \\
& $N$ & 0.000 & 0.012 \\
Partner's pleasure & $\begin{array}{l}\text { Pearson } \\
\text { correlation } \\
\text { Significance } \\
\text { (unilateral) } \\
N\end{array}$ & 579 & 579 \\
& 0.404 & -0.200 \\
& & 0.000 & 0.000 \\
\hline
\end{tabular}

Source: authors.

gay concept and to a lesser extent for the transphobia concept $(r=0.142$; significance 0.155$)$, as we can see in Table 5.

Finally, in Table 6, the analysis of correlations for dimension 5 (beliefs and values regarding sexuality), we find a statistically significant relationship between permissiveness toward occasional promiscuity and promiscuity as problematic $(r=0.230$; significance 0.000 ) and a negative correlation between the former and permissiveness toward prostitution ( $r=-0.219$; significance $0.000)$. There is also a positive correlation between premarital sex and the use of erotic materials $(r=0.212$; significance 0.000). There is a negative correlation between permissiveness toward prostitution and premarital sex $(r=-0.181$; significance 0.000 ), use of erotic materials ( $r=0.207$; significance 0.000 ), and sex $=$ love $(r=-0.210$; significance 0.000$)$. Use of erotic materials is directly related to premarital sex $(r=0.212$; significance 0.000$)$ and sex associated with love $(r=148$; significance 0.000$)$ and shows a negative correlation with promiscuity as problematic ( $r=-0.106$; significance 0.005$)$ and with permissiveness toward prostitution ( $r=-0.207$; significance $0.000)$. The sex $=$ love variable shows a strong correlation with promiscuity as problematic ( $r=0.222$; significance 0.000 ), premarital sex $(r=0.153$; significance 0.000$)$, and use of erotic materials ( $r=0.148$; significance 0.000$)$ and a negative correlation with permissiveness toward prostitution $(r=-0.210$; significance 0.000 ).

\section{Factor Analysis Results}

After applying the factor analysis to each dimension to establish the possible discourses that appear in the predictive rotation of the relationship between each dimension's variables (concerning potential differences based on age, country, and continent), statistically significant data was obtained.

As observed in Table 7, when we analyze the results relating to the first dimension, education sources, the data in the case of Europe and Spain, surpasses $75 \%$ of the variance explained. Spain follows that same trend being the country that makes the most difference in this issue.

TABLE 5 | Correlations for the sexual and gender identity concepts.

\begin{tabular}{|c|c|c|c|c|c|c|c|}
\hline & & Sexi & identity concept & Gay concept & $\begin{array}{l}\text { Gender identity } \\
\text { concept }\end{array}$ & Sexism concept & $\begin{array}{c}\text { Transphobia } \\
\text { concept }\end{array}$ \\
\hline \multirow[t]{2}{*}{ Religion } & \multicolumn{2}{|c|}{ Pearson correlation } & 0.251 & 0.230 & 0.055 & -0.017 & 0.142 \\
\hline & \multicolumn{2}{|c|}{$N$} & 53 & 53 & 53 & 53 & 53 \\
\hline \multirow[t]{2}{*}{ Lesbian concept } & \multicolumn{2}{|c|}{ Pearson correlation } & -0.036 & 0.781 & -0.163 & 0.166 & 0.047 \\
\hline & \multicolumn{2}{|c|}{ Significance (one-tailed) } & 0.354 & 0.000 & 0.044 & 0.042 & 0.314 \\
\hline \multicolumn{8}{|l|}{ Source: authors. } \\
\hline & & & $\begin{array}{c}\text { Youth } \\
\text { promiscuity as } \\
\text { problematic }\end{array}$ & Premarital sex & $\begin{array}{l}\text { Permissiveness } \\
\text { prostitution }\end{array}$ & $\begin{array}{l}\text { Use of erotic } \\
\text { materials }\end{array}$ & Sex $=$ love \\
\hline \multirow{2}{*}{\multicolumn{2}{|c|}{ Premarital sex }} & Pearson correlation & -0.001 & & -0.181 & 0.212 & 0.153 \\
\hline & & Significance (one-tailed) & 0.486 & & 0.000 & 0.000 & 0.000 \\
\hline \multirow{2}{*}{\multicolumn{2}{|c|}{$\begin{array}{l}\text { Permissiveness } \\
\text { prostitution }\end{array}$}} & Pearson correlation & -0.008 & -0.181 & & -0.207 & -0.210 \\
\hline & & Significance (one-tailed) & 0.423 & 0.000 & & 0.000 & 0.000 \\
\hline \multirow{2}{*}{\multicolumn{2}{|c|}{ Use of erotic materials }} & Pearson correlation & -0.106 & 0.212 & -0.207 & & 0.148 \\
\hline & & Significance (one-tailed) & 0.005 & 0.000 & 0.000 & & 0.000 \\
\hline \multirow{2}{*}{\multicolumn{2}{|c|}{ Sex $=$ love }} & Pearson correlation & 0.222 & 0.153 & -0.210 & 0.148 & \\
\hline & & Significance (one-tailed) & 0.000 & 0.000 & 0.000 & 0.000 & \\
\hline
\end{tabular}

Source: authors. 
If we focus on the second dimension, sexual habits, only Portugal and Brazil (and the two South American countries together) surpass $65 \%$ of the rotation (Table 8).

However, in the case of dimension 3, motivations, Portugal and Argentina are the ones that approach $75 \%$ of the variance explained (Table 9).

Regarding dimension 4, gender and sexuality concept, it should be noted that all elements approach 60\% (Table 10).

Finally, when we look at values and beliefs, the case of Argentina stands out at more than $70 \%$ of the variance explained (Table 11).

TABLE 7 | Factor analysis education dimension.

\begin{tabular}{lc}
\hline Variable & \% of variance explained \\
\hline Total matrix & 0.489 \\
$\leq 25$ & 0.476 \\
$>25$ & 0.492 \\
Spain & 0.781 \\
Portugal & 0.512 \\
Brazil & 0.439 \\
Argentina & 0.525 \\
Europe & 0.796 \\
Ibero-America & 0.564 \\
\hline
\end{tabular}

Source: authors.

TABLE 8 | Factor analysis habits dimension.

\begin{tabular}{lc}
\hline Variable & \% of variance explained \\
\hline Total matrix & 0.525 \\
$\leq 25$ & 0.406 \\
$>25$ & 0.527 \\
Spain & 0.421 \\
Portugal & 0.674 \\
Brazil & 0.696 \\
Argentina & 0.655 \\
Europe & 0.415 \\
lbero-America & 0.651 \\
\hline
\end{tabular}

Source: authors.

TABLE 9 | Factor analysis motivations dimension.

\begin{tabular}{lc}
\hline Variable & \% of variance explained \\
\hline Total matrix & 0.466 \\
$\leq 25$ & 0.645 \\
$>25$ & 0.641 \\
Spain & 0.472 \\
Portugal & 0.736 \\
Brazil & 0.573 \\
Argentina & 0.750 \\
Europe & 0.472 \\
Ibero-America & 0.647 \\
\hline
\end{tabular}

Source: authors.
TABLE 10 | Factor analysis gender and sexuality concept.

\begin{tabular}{lc}
\hline Variable & \% of variance explained \\
\hline Total matrix & 0.621 \\
$\leq 25$ & 0.629 \\
$>25$ & 0.633 \\
Spain & 0.521 \\
Portugal & 0.658 \\
Brazil & 0.632 \\
Argentina & 0.697 \\
Europe & 0.627 \\
Ibero-America & 0.633
\end{tabular}

Source: authors.

TABLE 11 | Factor analysis values - beliefs dimension.

\begin{tabular}{lc}
\hline Variable & \% of variance explained \\
\hline Total matrix & 0.466 \\
$\leq 25$ & 0.474 \\
$>25$ & 0.669 \\
Spain & 0.479 \\
Portugal & 0.658 \\
Brazil & 0.531 \\
Argentina & 0.732 \\
Europe & 0.471 \\
Ibero-America & 0.525
\end{tabular}

Source: authors.

\section{Results of Factor Analysis by Components Dimension 1. Education Sources}

The component that appears in the total matrix introduces variables 1, 2, and 3, academic sex education, contribution of sex education to personal development, and assessment of formal versus informal learning as significant, with a \% of variance explained of 0.489. In the University students, variables 2 and 3 stand out as the first component, the item's correlation weight shows a negative factor, the \% of variance is explained by 0.0490 . By ages and in all cases, the first component includes the three variables concerning the importance of education received. This variable is also the first component in three of the four countries studied, and it is not valued in Spain.

\section{Dimension 2. Habits: Sexual Behaviors and Practices}

Regarding sexual habits, the total matrix shows the three components as clearly differentiated. The first with respect to variables 5, 7, and 6: frequency of sexual relations, orgasm, and number of partners. The second concerns variables 10, 11, and 9, fidelity, sexual relations with samesex partners, and masturbation; and the third relates to variables 8 and 4, contraceptive use and age of first sexual relations. On the other hand, for the young women surveyed, significant differences can be seen in the importance attached to orgasm and the frequency of sexual relations, leaving 
component 9, which concerns masturbation, to the second component, as less significant. Contraceptive use is the third component.

In this dimension, the differences based on age should be noted: while respondents under the age of 25 emphasize variables $5,7,6$, and 4 (number of partners, orgasm, frequency of sexual relations, and age of first sexual relations) first, those over the age of 25 highlight variables 11,9 , and 10 (relations with same-sex partners, masturbation, and relations with third parties), and 11 and 9 correspond to the second component for those under that age. The second component is associated with first sexual relations, number of partners, and contraceptive use, and the third with orgasm and frequency of sexual relations.

When comparing countries, the most important components in Portugal and Spain were variables 5, 7, 4, and 6 (number of partners, orgasm, first sexual relations, and frequency of relations), while in Brazil and Argentina, they were variables 10 and 1 (relations with third parties and sexual relations with same-sex partners). Also noteworthy are the differences among countries regarding the perspective on contraceptive use, which is the second component in Spain and Portugal and the third in Brazil and Argentina.

\section{Dimension 3. Motivations: Expectations of Sexual Relations}

Regarding habits, the total matrix exhibits a single component with variables 14, 13, 17, and 12 (other person's pleasure, personal pleasure, reproduction, and partner's attractiveness). By age groups, respondents under the age of 25 considered the other person's pleasure to be more relevant, followed by personal pleasure and reproduction in the third place. For those over the age of 25, aside from the other person's pleasure, personal pleasure stood out compared to the other group. In all countries, the other person's and personal pleasure were emphasized, followed by reproduction and attractiveness as first components, with slight differences in the order of importance. In Brazil and Argentina, more importance was assigned to the partner's attractiveness. In all countries, emotional involvement in sexual relations appeared as the second component.

\section{Dimension 4. Sexual and Gender Identity Concept: Perception of Sexual Diversity}

In the total matrix, we find four components: the first with gay and lesbian, the second with transphobia and bisexuality, the third with homophobia and sexism, and the fourth with the sexual identity, transsexuality, and gender inequality concepts. For the first component, the people surveyed emphasize the lesbian and gay concepts. In the second component, sexism and homophobia stand. The third component corresponds to sexual identity and bisexuality. For the fourth component, overlap with gender inequality, and the latter add transphobia.

Looking at ages, it is important to note that younger respondents also emphasize variables 20 and 19, lesbian and gay, as the first component, although they diverge in the second component, as variables 26, 23, and 22 (transphobia concept, bisexuality, and gender inequality) are relevant to those under the age of 25, versus variables 25, 24, and 18 (homophobia, sexism, and sexual identity) for older respondents. Likewise, in the third and fourth components, differences based on age are observed. In the third, the relevance of sexism and homophobia stand out for those under the age of 25, versus sexual identity and transsexuality for the older group. In the fourth component, sexual identity and transsexuality are highlighted for those under 25, versus gender identities and transphobia for older respondents.

All countries also coincide with lesbian and gay concepts in the first component. For the second component, Spain and Portugal coincide with homophobia, sexism, and gender inequality, although Spain adds the transphobia concept. Brazil exhibits gender inequality and transsexuality versus Argentina with homophobia, transphobia, and transsexuality.

\section{Dimension 5. Values Regarding Sexuality. Beliefs and Values Regarding Sexuality}

The values of the total matrix exhibit two clear components. The first one corresponds to variables 34, 33, 31, and 37 (use of erotic materials, permissiveness toward prostitution, premarital sex, and sex for pleasure and not reproduction). The second component relates to variables $29,36,38$, and 35: promiscuity as problematic, respect for sexual diversity, greater male sexuality, and sexuality associated with love; along with the assessment of premarital sex and sex associated with pleasure. As for the second component, the students indicate: permissiveness toward prostitution, use of erotic materials, and promiscuity as problematic, casual relations. And the viewpoint that men have greater sexuality define this area, with respect for sexual diversity corresponding to the third component. In fourth place, a fourth component appears concerning pleasure and love with variables 28,37 , and 35 .

In the two age groups, those under the age of 25 exhibited in the first component more permissiveness toward occasional promiscuity and a stronger association of sexuality with pleasure and love, but not with reproduction. However, in this regard, the older group emphasized promiscuity as problematic and greater sexual activity in men. Secondly, the variables relating to the use of erotic toys, sex with third parties, and premarital relations (variables 34, 27, and 31) appeared as significant in both groups.

In terms of responses by country, the first component is the acceptance of casual relations with other people (variable 27) and a higher appreciation of sex associated with love (variable 35) but not reproduction. Prostitution is not viewed negatively in any country, and permissiveness toward its practice is observed in all of them. There is a positive assessment of sexual diversity (variable 36), although it appears in the third or fourth component in all of them. In both Spain and Portugal, the first component corresponds to permissiveness toward casual relations and the link between sex and love, which is the third component in Brazil and Argentina, which value the use of erotic materials (variable 34 in Brazil), the masculinization of sexuality 
(variable 38), and the problem of promiscuity (variable 29) as the first component.

\section{DISCUSSION: PERCEPTION AND EXPERIENCE OF SEXUALITY AMONG YOUNG PEOPLE}

The following is a discussion of the results in each dimension of our study as they relate to the emotional well-being of young people and the categories based on the WHO's recommendations (2010, 2018). The latter are linked to the sex education that the United Nations Educational Scientific and Cultural Organization [UNESCO] (2009) studies and other recent research have found to be important to young people's development in terms of sexuality.

\section{Dimension 1. Education Sources: Level and Experience of Sex Education Received}

Our study shows the importance and assessment of the sex education received by the young people we surveyed in four countries. In all cases, this instruction was provided mainly in secondary school and considered significant for personal development. It is relevant that when asked about the value of academic education versus information/learning obtained in informal contexts, the respondents clearly placed more value on the latter from the perspective of well-being and development, and this was especially the case of those under the age of 25. As the United Nations Educational Scientific and Cultural Organization [UNESCO] (2009) indicates, a comprehensive education based on scientific evidence is necessary from early childhood to encourage greater autonomy and safety during young adulthood. In this regard, education defines a higher degree of emotional well-being by providing more knowledge and a positive attitude toward sexuality.

\section{Dimension 2. Habits: Sexual Behaviors and Practices}

In general, concerning sexual behaviors and habits, the results reveal a clear link between sexuality and the pursuit of pleasure and personal satisfaction in terms of the frequency of sexual relations and the number of partners; these aspects are more relevant than those linked to reproduction or stable relationships. Orgasm and autoerotism were key references in the minds of young people in this dimension. Masturbation appears as a habitual and recognized practice, although, as we will see in dimension 5 concerning values and beliefs about sexuality, it is viewed less positively. It should also be noted that prevention or contraceptive use was not a central or relevant theme for sexual habits, although it was more marked for those under the age of 25. Although one of the factors of emotional well-being around sexuality, according to the $\mathrm{WHO}$, concerns prevention, including both safe sex and contraceptive use, the study reveals that risky habits persist in the youth population surveyed. This is linked to sexuality in which the frequency of sexual intercourse and the number of partners prevail over safety in the pursuit of satisfaction. In this regard, when observed in detail, there are some clear differences in sexual habits among the countries in our study, reflected in both the component and correlation tests: while in Portugal and Spain, frequency and number of partners are key aspects of sexual behavior, in Brazil and Argentina, relations with third parties and homosexual relations stand out first, although religion and, to a lesser extent, the age of first sexual relations have a significant correlation with perceived sexual behaviors. In this regard, the study showed that most young people have their first sexual experiences between the ages of 15 and 18. Following the guidelines of the United Nations Educational Scientific and Cultural Organization [UNESCO] (2018); Fonner et al. (2014), educational programs designed to provide more information combined with instruction that delays the age of first sexual relations result in safer practices. It should be noted that early sexual relations carry a higher probability of risky behaviors and unsafe practices and reduce emotional well-being for the young person in the long term.

\section{Dimension 3. Motivations: Expectations of Sexual Relations}

According to the results of our study, in terms of motivations, the most emphasized aspects concern to one's own satisfaction and pleasure and that of one's partner, together with emotional bonds, and to a lesser degree, reproduction, which correlates negatively with sexual satisfaction. In this sense, emotional factors were more important to women, a fact that coincides with the results of several recent studies (Friedrich et al., 2000; Larrañaga et al., 2012; López et al., 2011). The young students showed a stronger inclination toward emotional and relationship and valued that men are more directly oriented toward excitement and pleasure (Faílde et al., 2008). However, reproduction was an inverse factor to pleasure, exhibiting a clear separation of these two aspects for all the young people surveyed.

In different countries, emotional involvement appears as a second component to shared pleasure with one's partner and the importance of giving pleasure in the case of women. Own orgasm was equally important for all age groups, yet more significant in those under the age of 25 . It should be noted that the attractiveness of one's partner did stand out more as a motivation for sexual relations in countries such as Brazil and Argentina. Motivations toward sexuality reveal the extent to which young people perceive sexual function as an important dimension of their relationships. In this regard, one of the categories established by the WHO for young people's emotional well-being around sexuality links motivations to the expectations learned in the social and community context ( $W H O$ recommendations on adolescent sexual health and reproductive health and rights, 2018 and the importance of the environment in encouraging young people's habits and behaviors. Therefore, beyond the heterogeneity exhibited by the different countries in our study, CSE takes on great importance in this area, as it defines aspects concerning gender differences and the importance of emotional bonds and reproduction. This makes an impact on young people's emotional development and safety, 
especially at a stage of life in which these aspects seem less important to them.

\section{Dimension 4. Sexual and Gender Identity Concept: How Sexual Diversity Is Perceived}

The results of the questionnaire indicate that the perception of sexuality and emotional-sexual diversity and gender identity is quite varied, containing some heteronormative biases. Although sexual diversity is accepted, it is barely represented as a value in one's own sexual experience. Young people adopt liberal attitudes toward sexuality and especially toward what is more socially visible and acceptable (García-Vega et al., 2017). The discourse of young university students about sexual diversity is becoming more variable and dynamic, perhaps because they are beginning to accept and integrate behaviors that fall outside of the norm dictated by the patriarchy or dominant hegemony. However, we can still see that transsexuality remains hidden and barely accepted, potentially, as López (2005) points out, due to the predominance of normative values associated with conservative morals.

Also noteworthy is the prevalence of low-intensity sexism, given that the variables related to gender inequalities did not have a prevalent place among women in any of the countries analyzed, appearing only as a secondary component in the tests performed. The fact that the study also reveals a certain degree of permissiveness toward prostitution indicates that young women are more vulnerable than men in their relationships, which can impact their health, safety, and personal well-being. This is a sign of the emergence of new scenarios of vulnerability for young people in increasingly globalized societies, with gender violence and sexual exploitation as some of their most worrisome manifestations (Melendro et al., 2018). The World Health Organization [WHO] (2018) points out in this regard that the permanence of conditions of social inequality increases violence toward women, especially at this stage of life. Therefore, all its recommendations include the gender perspective in sex education starting in childhood.

\section{Dimension 5. Values Regarding Sexuality. Beliefs and Values Regarding Sexuality}

Finally, in terms of young people's beliefs about sexuality, the results of this study indicate that sexuality is far more associated with pleasure and love than with reproduction. In modern society, according to Beck and Beck-Gernsheim (2001), there is no competent external moral authority on matters of love. Sexuality occupies a space of its own within the process of defining one's identity and as an instrument of the free expression of desires. Young people have free reign of their bodies, allowing them to experience sexual pleasure with a spontaneity unencumbered by cultural and reproductive restrictions (Giddens, 2004).

At the same time, as pleasure is pursued, there is a relaxation of the norms of sexual exclusiveness between partners sexual exclusiveness here has a role in the relationship to the degree to which the partners mutually deem it desirable or essential (Giddens, 2004, p. 64). Although promiscuity is negatively assessed as a source of problems in young people, our study also reveals a certain degree of tolerance toward casual relations, or toward sexual relations with third parties even in the context of a stable relationship, especially for those under the age of 25 . Reproduction is no longer linked to sexuality and relationships, although this aspect was more relevant in Spain and Portugal than in other countries.

Another noteworthy aspect of the results is the relevance of masturbation: young people report it as a habitual practice, although it appears undervalued. This perspective is perhaps still conditioned by orthodox religious positions and traditional cultural constraints that associate it with multiple negative connotations (Patton, 1986). Due to these ideas, circulated in Western society for decades, in many situations (for example, a stable relationship), masturbation generates feelings of sexual guilt (Santos et al., 2013).

In conclusion, our findings point to the need to expand young people's knowledge and awareness of the complexity of sexuality and sexual health, linking it to emotional and relational aspects. It is necessary to implement CSE, as recommended in the guidelines of the World Health Organization [WHO] (2018) and United Nations Educational Scientific and Cultural Organization [UNESCO] (2018), that corrects stereotypes about diversity or equality that persist in educational institutions (Bejarano, 2017). The goal is to provide young people with knowledge, skills, attitudes, and values that empower them, allowing them to enjoy sexuality in a safe, healthy way and with a high level of long-term emotional well-being. Our study shows that although the sexual practices of young university students are more open and diverse today, they are not free from conflicts and problems associated with the experiences they entail. There is a clear dissociation between the reported behaviors and the values with which these behaviors are judged or perceived. The social and cultural context defines the mental framework from which one's own sexual relations are experienced according to hegemonic social normativity. This is reflected in the fact that issues such as sexual diversity, equality in relationships between men and women, and practices outside the predominant heterosexual models did not have a very central position in any of the dimensions analyzed. On the other hand, the study also indicates a divergence among expectations regarding emotional relationships, love, reproduction, and sexual pleasure.

A comprehensive, complex and pluralistic vision of sexuality, as reflected in the baseline categories of the $\mathrm{WHO}$ and UNESCO in this study, would mean the integration of all these aspects into sexual experiences. This would result in a higher level of emotional well-being in young people by encouraging them to explore sexuality in a way less conditioned by the sociocultural parameters still in force. According to the World Health Organization [WHO] (2010), the resistance to CSE starting in childhood stems from a prejudiced assessment thereof; as a result, sexuality is still approached tangentially in academic and social education in most societies. As demonstrated, sexuality education does not imply greater sexualization at an early age, but quite 
the opposite: it ensures a higher level of health and safety, better preparation to position one's sexual experience in a respectful relational framework, and acquisition of solid knowledge that allows one's own identity and sexual experience to be explored autonomously during this stage of life.

\section{DATA AVAILABILITY STATEMENT}

The datasets generated for this study are available on request to the corresponding author.

\section{ETHICS STATEMENT}

Ethical review and approval was not required for the study on human participants in accordance with the local legislation and institutional requirements. Written, informed consent was inferred through the completion of the questionnaire.

\section{AUTHOR CONTRIBUTIONS}

All the authors of this article have made an equal contribution to its completion and to the research process: literature review, methodological and instrument design, field work, analysis, and discussion of the results.

\section{REFERENCES}

Alencar, R., Silva, L., Arlindo, F., and Da Silva, R. E. (2008). Desenvolvimento de uma proposta de educação sexual para adolescentes. Ciência Educ. Bauru 14, 159-168. doi: 10.1590/S1516-73132008000100011

Altmann, H. (2009). Educação sexual em uma escola: da reprodução à prevenção. Cadernos Pesquisa São Paulo 39, 175-200. doi: 10.1590/S010015742009000100009

Andrade, H. H. S. M., de Mello, M. B., Sousa, M. H., Makuch, M. Y., Bertoni, N., Faúndes, A., et al. (2009). Mudanças no comportamento sexual de adolescentes de escolas públicas no brasil após um programa de educação sexual. Cadernos Saúde Pública Rio Janeiro 25, 1168-1176. doi: 10.1590/S0102311X2009000500023

Bakker, F., and Vanwesenbeeck, I. (2006). Seksuele Gezondheid in Nederland. Eburon: Delft.

Beck, U., and Beck-Gernsheim, E. (2001). El normal Caos Del Amor. Las nuevas formas de la Relación Amorosa. Barcelona: Paidós.

Bejarano, M. T. (2017). "Educación en sexualidad para prevenir la violencia LGTBI en las aulas," in Nuevas Violencias, Nuevos Contextos De Intervención Educativa, eds M. R. Graó, R. Marí, and N. Hipólito (Barcelona: FC Barcelona), 85-87.

Borrego, N. G., and Enrì̀quez, M. P. (2013). Queì preceptos teoìricos y metodoloìgicos deben sustentar el estudio y la educacioìn integral de la sexualidad en adolescentes y joìvenes? Rev. Sex. Soc. 19, 17-30.

Calado, M., Lameiras, M., and Rodriìguez, Y. (2004). Influencia de la imagen corporal y la autoestima en la experiencia sexual de estudiantes universitarias sin trastornos alimentarios. Intern. J. Clin. Health Psychol. 4, 357-370.

Carrera-Fernández, M. V., Lameiras-Fernaìndez, M., and Rodriguez, Y. (2012). Hacia una educacioìn sexual que todaviìa es posible. Inform. Psicol. 103, 4-14.

Claramunt, C., and Huertas, L. (1999). Ideas, conocimiento y actitudes sexuales previas en adolescentes (13-15 anpos). Inform. Psicol. 69, 30-37.

Crawford, M., and Popp, D. (2003). Sexual double standards: A reviewand methodological critique of two decades of research. J. Sex Res. 40, 13-26. doi: $10.1080 / 00224490309552163$

\section{FUNDING}

This article is the result of research conducted by the Education and Society Research Group (GIES) and funded by University of Castilla-La Mancha and the European Regional Development Fund (ERDF) during the 2016 to 2018 period (REF. GI20163554), in the framework of the study Sexuality and equality education: A comparative analysis of Spain, Portugal, Brazil and Argentina.

\section{ACKNOWLEDGMENTS}

We would like to thank the faculty and students of the universities that collaborated on this study: GIES Group in the School of Social Sciences and the Schools of Education of Toledo and Ciudad Real at University of Castilla-La Mancha (Spain) and especially Dr. María Teresa Bejarano Franco; Institute of Education - IE and the Center for Environmental Education, Sciences and Math (Ceamecim), Federal University of Rio Grande - FURG. Superior School of Education (Coimbra, Portugal) and the Department of Education at University of Aveiro, Portugal; Department of Psychology and Pedagogical Sciences at CAECE University, Buenos Aires. We would also like to express our appreciation to Dr. Inmaculada Herranz Aguayo of the School of Social Sciences at University of CastillaLa Mancha.

Davidson, S., Bell, R., La China, M., Holden, S., and Davis, S. (2009). The relationship between self-reported sexual satisfaction and general well-being in women. J. Sex Med. 6, 2690-2697. doi: 10.1111/j.1743-6109.2009.01406.x

Duckworth, A., Steen, T. A., and Seligman, M. (2005). Positive psychology in clinical practice. Annu. Rev. Clin. Psychol. 1, 629-651. doi: 10.1146/annurev. clinpsy.1.102803.144154

European Union Agency for Fundamental Rights (2014). Fundamental Rights: Challenges and Echievements in 2013. Annual Report. Belgium: European Union Agency for Fundamental Rights, doi: 10.2811/69283

Faílde, J. M., Lameiras, M., and Bimbela, J. L. (2008). Praìcticas sexuales de chicos y chicas espanpoles de 14-24 anpos de edad. Gaceta Sanitar. 22, 511-518. doi: 10.1016/S0213-9111(08)75347-0

Fallas-Vargas, M. A., Artavia, C., and Gamboa, A. (2012). Educacioin sexual: orientadores y orientadoras desde el modelo biograifico y profesional. Rev. Electroin. Educ. 16, 53-71. doi: 10.15359/ree.16-esp.7

Fonner, V. A., Armstrong, K. S., Kennedy, C. E., O’Reilly, K. R., and Sweat, M. D. (2014). School based sex education and HIV prevention in low- and middleincome countries: A systematic review and meta-analysis. PLoS One 9:e89692. doi: 10.1371/journal.pone.0089692

Friedrich, W. N., Sandfort, T., Oostveen, J., and Cohen-Kettenis, P. (2000). Cultural differences in sexual behavior: 2-6 year old Dutch and American children. J. Psychol. Hum. Sex. 12, 117-129. doi: 10.1300/J056v12n01_08

García-Vega, E., Menendez, E., Fernandez, P., and Cuesta, M. (2012). Sexualidad, anticoncepcioìn y conducta sexual de riesgo en adolescentes. Intern. J. Psychol. Res. 5, 79-87.

García-Vega, E., Menendez, E., Garcia, P., and Rico, R. (2010). Influencia del sexo y del geìnero en el comportamiento sexual de una poblacioìn adolescente. Psicothema 22, 606-612.

García-Vega, E., Rico, R., and Fernaìndez, P. (2017). Sexo, roles de geìnero y actitudes sexuales en estudiantes universitarios. Psicothema 29, 178-183.

Generelo, J. (2016). La Diversidad sexual y de Geìnero en el sistema Educativo: ¿queì sabemos sobre ella? Índice. Rev. Estadiist. Soc. 66, 29-32.

Giddens, A. (2004). La Transformación de la Intimidad: Sexualidad, Amor Y Erotismo En Las Sociedades Modernas. Madrid: Cátedra. 
Kornblit, A., and Ezequiel, S. (2015). Actitudes y prácticas sexuales de los jóvenes escolarizados en el nivel medio de la enseñanza pública argentina £nuevos patrones? Educación. Lenguaje y Sociedad. 12, 1-27. doi: 10.19137/els-2015121205

Langlois, A., and Anderson, D. (2002). Resolving the quality of life/well-being puzzle: toward a new model. Can. J. Reg. Sci. 25, 501-512.

Larrañaga, E., Yubero, S., and Yubero, M. (2012). Influencia del geìnero y del sexo en las actitudes sexuales de estudiantes universitarios espanpoles. Summa Psicol. UST 9, 5-14. doi: 10.18774/448x.2012.9.89

Levin, R. J. (2007). Sexual activity, health and well-being: Thebeneficial roles of coitus and masturbation. Sex. Relationsh. Ther. 22, 135-148. doi: 10.1080/ 14681990601149197

Li, C., Cheng, Z., Wu, T., Liang, X., Gaoshan, J., Li, L., et al. (2017). The relationships of school-based sexuality education, sexual knowledge and sexual behaviors-a study of 18,000 Chinese college students. Reproduct. Health 14, 103-112. doi: 10.1186/s12978-017-0368-364

López, F. (2005). La Educacioin Sexual. Madrid: Biblioteca Nueva.

López, F. (2015). Eitica de las Relaciones Sexuales Y Amorosas. Madrid: Piraìmide.

López, F., Carcedo, R., Fernaìndez-Rouco, N., Blaizquez, M. I., and Kilani, A. (2011). Diferencias sexuales en la sexualidad adolescente: afectos y conductas. Anales Psicol. 27, 791-799.

Marí, R., Barranco, R., and Martínez, I. (2019). "Educar en sexualidades e igualdad en educación social desde una perspectiva feminista," in Educación en Sexualidad E Igualdad. Discursos y Estrategias Para La Formación De Docentes Y Educadores Sociales, eds M. T. Bejarano and R. Marí (Madrid: Dykinson), 31-49.

Martín, M., Ferraris, S., and Langsam, M. (2018). Jóvenes, enfermedades de transmisión sexual y derechos. Panorama nacional y regional en Argentina. Ciência Saúde Coletiva 23, 2835-2848. doi: 10.1590/1413-81232018239. 13382018

Martiìnez-Ailvarez, J. L., Carcedo, R. J., Fuertes, A., Vicario-Molina, I., FernaindezFuertes, A. A., and Orgaz, B. (2012). Sex education in Spain: teachers' views of obstacles. Sex Educ. 12, 425-436. doi: 10.1080/14681811.2012.691876

Melendro, M., De Juanas, A., and Rodríguez, A. E. (2018). Pedagogía Social. Retos y Escenarios Para La Acción Socioeducativa. Madrid: UNED.

Mellor, D., Fuller, M., McCabe, M., and Ricciardelli, L. (2010). Body image and self-esteem across age and gender: a short-term longitudinal study. Sex Roles 63, 672-681. doi: 10.1007/s11199-010-9813-3

Moore, N. B., and Davidson, J. K. (2006). College women and personal goals: cognitive dimensions that differentiate risk-reduction sexual decisions. J. Youth Adolesc. 35, 574-589. doi: 10.1007/s10964-006-9041-x

Munpoz, M. A., and Revenga, M. (2005). Aprendizaje y educacioìn afectivo-sexual: una revisioin de los planteamientos iniciales del aprendizaje de las cuestiones sexuales. Rev. Galego Portug. Psicol. Educ. 10, 45-56.

Nascimento, B., Spindola, T., Pimentel, M. R., Ramos, R., De Almeida, R. C., Santos, R., et al. (2018). Sexual behavior among college students and care for sexual and reproductive health. Enferm. Glob. 17, 237-269.

Patton, M. S. (1986). Twentieth-century attitudes toward masturbation. J. Relig. Health. 25, 291-302. doi: 10.1007/BF01534067

Petersen, J. L., and Hyde, J. S. (2010). A meta-analytic review of re- search on gender differences in sexuality. Psychol. Bull. 136, 21-38. doi: 10.1037/a001 7504

Platero, R., and Rosón, M. (2012). De la 'parada de los monstruos' a los monstruos de lo cotidiano: la diversidad funcional y la sexualidad no normativa. Feminismos 19, 127-142. doi: 10.14198/fem.2012.19.08

Rodríguez, O. R. (2010). Relacioìn entre satisfaccioìn sexual, ansiedad y praìcticas sexuales. Pensamient. Psicol. 7, 41-52.

Rodríguez-Carrión, J., and Traverso-Blanco, C. I. (2012). Conductas sexuales en adolescentes de 12 a 17 anpos de Andaluciàa. Gaceta Sanitar. 26, 519-524. doi: 10.1016/j.gaceta.2012.02.005
Salvador, M., Garciìa-Gailvez, C., and De la Fuente, M. (2010). Creencias y estrategias para el control del peso, satisfaccioin con la imagen corporal y autoestima. Eur. J. Edu. Psychol. 3, 257-273.

Santín, C., Torrico, E., Loìpez, M. J., and Revilla, C. (2003). Conocimiento y utilizacioin de los meitodos anticonceptivos y su relacioìn con la prevencioin de enfermedades de transmisioìn sexual en joìvenes. Anales Psicol. 19, 81-90.

Santos, I. P., Sierra, J. C., and Monge, F. S. (2013). Inventario de Actitudes Negativas hacia la Masturbación: Validez, Fiabilidad y una Propuesta de una Versión Reducida para Adolescentes. Rev. Argent. Clín. Psicol. 8, 57-65.

Scott, V., Sandberg, G., Harper, M., and Miller, R. (2012). The impact of depressive symptoms and health on sexual satisfaction for older couples: implications for clinicians. Contemp. Fam. Ther. 34, 376-390. doi: 10.1007/s10591-0129198-2

Sierra, J. C., Rojas, A., Ortega, V., and Martiìn-Ortiz, J. D. (2007). Evaluacioìn de actitudes sexuales machistas en universitarios: primeros datos psicomeitricos de las versiones espanbolas de la Double Standard Scale (DSS) y de la rape supportive attitude sca- le (RSAS). Intern. J. Psychol. Psychol. Ther. 7, 41-60.

Snyder, C. R., and Lopez, S. J. (eds) (2005). Handbook of Positive Psychology. Oxford: Oxford University Press.

United Nations Educational Scientific and Cultural Organization [UNESCO] (2009). International Technical Guidance on Sexuality Education: An Evidenceinformed approach for schools, teachers and health educators. Paris: UNESCO. Available online at: http://unesdoc.unesco.org/images/0018/001832/183281e. pdf

United Nations Educational Scientific and Cultural Organization [UNESCO] (2010). Orientaciones Técnicas Internacionales sobre Educación en Sexualidad. Enfoque Basado En Evidencia Orientado A Escuelas, Docentes Y Educadores De La Salud. Paris: UNESCO.

United Nations Educational Scientific and Cultural Organization [UNESCO] (2018). Orientaciones Técnicas Internacionales Sobre Educación En Sexualidad: Un Enfoque Basado En La Evidencia. Paris: UNESCO.

Viejo, C., Gómez-López, M., and Ortega-Ruiz, R. (2018). Adolescents psychological well-being: a multidimensional measure. Int. J. Environ. Res. Public Health 15:2325. doi: 10.3390/ijerph15102325

Whipple, B., Knowles, J., and Davis, J. (2003). The Health Benefits Of Sexual Expression. White Paper. New York: Planned Parenthood Federation of America, Inc, and the Society for the Scientific Study of Sexuality (Updated 2007 by Gianotten, W. L., \& Golub, D.). Available online at: https://www. plannedparenthood.org/files/3413/9611/7801/Benefits_Sex_07_07.pdf

World Health Organization [WHO] (2002). Defining Sexual Health: Report Of A Technical Consultation On Sexual Health. Geneva: WHO.

World Health Organization [WHO] (2010). Informe Sobre La Salud En El Mundo: La Financiacioin De Los Sistemas De Salud: El Camino Hacia La Cobertura Universal. Geneva: WHO.

World Health Organization [WHO] (2018). Recomendaciones de la OMS Sobre Salud Y Derechos Sexuales Y Reproductivos De Los Adolescentes. Geneva: WHO.

Zubieta, E., Muratori, M., and Fernaindez, O. (2012). Bienestar subjetivo y psicosocial: explorando diferencias de geinero. Salud Soc. 3, 066-076.

Conflict of Interest: The authors declare that the research was conducted in the absence of any commercial or financial relationships that could be construed as a potential conflict of interest.

Copyright (c) 2020 Marí-Ytarte, Moreno-López and Barranco-Barroso. This is an open-access article distributed under the terms of the Creative Commons Attribution License (CC BY). The use, distribution or reproduction in other forums is permitted, provided the original author(s) and the copyright owner(s) are credited and that the original publication in this journal is cited, in accordance with accepted academic practice. No use, distribution or reproduction is permitted which does not comply with these terms. 